\title{
FINIITVERBI MÕJU OBJEKTI KÄÄNDELE DA-INFINITIIVIGA OBJEKTIKONSTRUKTSIOONIS
}

\author{
DAVID OGREN
}

$\mathrm{E}$ esti keele objekti vormivaheldust kirjeldatakse tavaliselt kolme põhireegli abil. Nimelt esineb totaalobjekt ainult siis, kui on täidetud kõik järgmised kriteeriumid:

1) objekt laiendab jaatavat verbivormi,

2) tegevus on piiritletud, st lõpetatud//õpuleviidav ning tulemuslik,

3) objekt on kvantitatiivselt piiritletud.

Vastasel juhul kasutatakse partsiaalobjekti. Ümberpööratuna võib need reeglid sõnastada nii, et partsiaalobjekti kasutatakse eitava verbivormi, piiritlemata tegevuse ja/või piiritlemata objekti puhul.

Esimene ja kolmas reegel on suhteliselt selged. Ei ole raske otsustada, millal on tegemist jaatava ja millal eitava verbivormiga. Objekti piiritle(ma)tuse küsimus on samuti lihtne: objekt on piiritletud siis, kui see moodustab mingisuguse terviku. Seega tähendab söön lõhe seda, et söön ära terve kala, söön lõhet aga seda, et söön ära mingi (ebamäärase, täpsustamata) osa kalast. Teine reegel, mis puudutab tegevuse piiritle(ma)tust, on aga palju hägusem. Kõigepealt on tulemuslikkuse mõiste üsna subjektiivne: mida loetakse tulemuslikuks tegevuseks ja mida mitte? Vastused ei pruugi olla loogilised ja järjepidevad, mida näitab nende keeltevaheline varieeruvus (näiteks eesti keele tundeverbid nägema ja tundma käituvad piiritlematutena, nõudes partsiaalobjekti, samal ajal kui nende samatähenduslikud soome keele vasted esinevad koos totaalobjektiga). Teine küsimus on, mida täpselt tegevuse all mõeldakse. Kui verbifraasis on ainult üks verb, siis ongi ainult üks tõlgendus, aga finiitverbist ja infinitiivist koosnevates verbiühendites on võimalikke tõlgendusi vähemalt kolm. Näiteks lauses Ta kardab kaotada oma töökoh(t)a võib põhitegevuseks pidada kas kartmist, kaotamist või kaotuse kartmist (terve verbiühend ühe kompleksse tegevusena). Tõlgendusest on tingitud ka objekti käände võimalik varieerumine selles lauses. Kui objekti käänet määravaks verbiks on finiitverb, kasutatakse partsiaalobjekti, kuna kartma on partitiivverb; kui määravaks osutub infinitiiv kaotada, kasutatakse pigem totaalobjekti. Tegemist on kahe vastandliku, omavahel võistleva motivatsiooniga, ${ }^{1}$ mille kokkupõrke tulemusest sõltub objekti kääne.

Artiklis püütakse leida vastus(t) küsimusele, kuidas mõjutab finiitverb seda laiendavas $d a$-infinitiiviga fraasis esineva objekti käände valikut. Võrreldakse erinevaid verbe, mis selles konstruktsioonis finiitverbina esinevad, ning vaadeldakse, millised neist soodustavad kõige rohkem kas partsiaal- või totaalobjekti. Üritatakse leida objekti käände osas sarnaselt käituvate finiit-

${ }^{1}$ Hea ülevaate võistlevatest motivatsioonidest kui keelenähtuste analüüsi lähtekohast pakub kogumik „Competing Motivations in Grammar and Usage” (McWhinney jt 2014). 
verbide semantilisi ühisjooni. Uurimuses kasutatud keelematerjal pärineb eesti keele veebilehtede korpusest etTenTen.

Artikkel koosneb kuuest osast. Esimeses osas kirjeldatakse artikli teoreetilist tausta ning võetakse lühidalt kokku uurimisteema varasemad käsitlused. Teises osas kirjeldatakse uurimismaterjali ja -meetodit. Osades 3-5 esitatakse kvantitatiivsed uurimistulemused ning hinnatakse erinevate võimalike selgituste sobivust tulemuste kirjeldamiseks. Viimases osas võetakse artikkel kokku ning arutletakse tulemuste teoreetilise tähtsuse üle.

\section{Teoreetiline taust}

\subsection{Objektikonstruktsioon ja selle alltüübid}

Üks sagedasemaid $d a$-infinitiivi sisaldavaid lausemalle on see, kus $d a$-infinitiiviga fraas laiendab finiitverbi. Selles konstruktsioonis varieerub objekti kääne ka siis, kui nii $d a$-infinitiiviga kirjeldatud tegevus kui ka selle objekt on selgelt piiritletud. Mõned näited:

(1) Valitsus tahab jätta kultuuritöötajate palga endiseks.

(2) Mees, kes soovib teha abieluettepanekut, võib artikli autorite sõnul ajas pisut tagasi vaadata, sest naised annavad tihti selgeid vihjeid.

(3) Koodi abil saate hõlpsasti leida vastuse esitatud küsimusele.

(4) Samasooliste abielu keelu vastased on väitnud, et sellist põhiseaduse muudatust tohib hääletusele panna ainult osariigi parlament kahekolmandikulise häälteenamusega.

(5) Tootjatel soovitatakse koguni vastav väide pakendilt kõrvaldada.

(6) Kütuseseire andmekogust leiab teavet tanklates müüdud mootorikütuse kvaliteedikontrollide tulemuste kohta, mis võimaldab tarbijal teha keskkonnateadlikku valikut kütuse ostmisel.

Näidetes 1-6 esinevates $d a$-infinitiiviga fraasides, kui nad oleksid finiitsed verbifraasid, oleneks objekti kääne ainult aspektist, konkreetsemalt sellest, kas tegevust mõeldakse jätkuvana või lõpetatud/lõpetatavana. Näiteks lausel 2 põhineval finiitlausel mees teeb abieluettepaneku(t) oleks partsiaalobjekt vastuvõetav ainult siis, kui kirjeldataks parajasti toimuvat sündmust, mitte tulevikus toimuvat. Objekti käände varieerumine sellistes finiitlausetes on täiesti reeglipärane, olles seletatav piiritletuse kriteeriumi abil. Kui aga needsamad lekseemid esinevad finiitverbi laiendavas $d a$-infinitiiviga fraasis, varieerub objekti kääne moel, mida ei ole võimalik taandada piiritletuse põhimõttele. Näidetes 1, 3 ja 5 kasutatakse totaalobjekti, näidetes 2, 4 ja 6 aga partsiaalobjekti, kuigi infiniitse verbifraasi piiritletuse seisukohalt on kõik kuus lauset samasugused.

Ülaltoodud näidetest selgub ka, et on olemas eri tüüpi verbe, mis esinevad vaadeldavas konstruktsioonis finiitverbina. Need võib jagada kolme rühma:

1) soovi, kavatsust või muud tunnet väljendavad verbid (nt tahtma, soovima);

2) modaalverbid (nt saama, tohtima);

3) soovitust/käsku/võimaldamist jms väljendavad verbid (nt soovitama, võimaldama). 
Pille Penjam käsitleb neid kolme tüüpi eraldi konstruktsioonidena, vastavalt 1) soovimis-kavatsemiskonstruktsioon, mis väljendab „agendi soovi või kavatsust sooritada $d a$-infinitiivi tarindi abil väljendatud tegevus" (Penjam 2008: 75), 2) modaalkonstruktsioon, milles $d a$-infinitiiviga fraas laiendab modaalverbi (Penjam 2008: 124) ja 3) võimaldamis-kohustamiskonstruktsioon, milles finiitverbi tegevussubjekt erineb infiniitse verbi omast ning infiniitse verbi tegevussubjekt, kui seda üldse mainitakse, esineb adessiivis (Penjam 2008: 82). Näited 1 ja 2 esindavad soovimis-kavatsemiskonstruktsiooni, 3 ja 4 modaalkonstruktsiooni ning 5 ja 6 võimaldamis-kohustamiskonstruktsiooni.

Käesolevas uurimuses käsitletakse neid kolme konstruktsiooni ühe üldisema konstruktsiooni alltüüpidena. Seda üldisemat konstruktsiooni, mille määravaks tunnuseks on see, et $d a$-infinitiiviga fraas laiendab finiitverbi, nimetatakse selles artiklis objektikonstruktsiooniks, kuna $d a$-infinitiiviga fraas esineb selles objekti rollis (olles see, mida tahetakse, soovitatakse vms). Rangelt võttes on $d a$-infinitiiviga fraas modaalkonstruktsioonis enamasti pigem liitpredikaadi osa kui objekt, aga vormilise sarnasuse tõttu käsitletakse siin kõiki kolme lausemalli koos, sama ühisnimetuse all.

\subsection{Varasemad käsitlused}

Objekti käände ebareeglipärast varieerumist $d a$-infinitiivi ja finiitverbi ühendit sisaldavates verbifraasides on tähele pannud mitmed eesti keele uurijad. Johannes Aavik väitis, et totaal- ja partsiaalobjekti vahel on tähenduserinevus ning käändevalik sõltub sellest, mida tahetakse rõhutada: „Kuid toonitatagu, et osaobjekt sobib ainult siis, kui tähtsam on tahtmine, oskamine, suutmine üldse; kui aga tähtsam on infinitiiviga osutatud tegevus, eriti üksikus, konkreetses juhtumis, peab olema täisobjekt, kui infinitiiv seda nõuab" (Aavik 1936: 133). Ka Valter Tauli (1980: 60) näeb partsiaal- ja totaalobjekti vahel tähenduserinevust, nimelt et „partsiaalobjekt väljendab nõrgemat, totaalobjekt kindlamat soovi, soovitust, tahet, kavatsust; partsiaalobjekti puhul ei väljendata, totaalobjekti puhul väljendatakse võimalikku tulemust". Veidi teistsugusel seisukohal on Mati Erelt (2006: 42), kes nendib, et „soovimist, tahtmist või kavatsemist väljendavate verbide puhul võib esineda nii osa- kui ka täissihitis”, kuid lisab, et „võimalik tõlgenduserinevus on ebaoluline”. Uurijate arvamuste lahknevus peegeldab nii kindla reeglistiku puudumist kui ka otsustusprotsessi subjektiivsust. Aavik ei seleta, millistel tingimustel tuleks pidada tahtmist, oskamist jms tähtsamaks kui infinitiiviga osutatud tegevust (või vastupidi). Tauli kirjeldusest jääb ebaselgeks, kus jookseb piir nõrga ja tugeva soovi/tahte/kavatsuse vahel; tugevus on oma olemuselt skalaarne tunnus, seevastu partsiaal- ja totaalobjekti puhul on tegemist binaarse vastandusega. Erelti arvamusest võiks järeldada, et objekti käände varieerumine selles konstruktsioonis sõltub pigem keelekasutaja suvast kui mingisugusest semantilisest eristusest, mis ei aita kuidagi selle varieerumise üksikasjadele seletuste leidmisel.

Lisaks eeltoodud üldistele põhimõtetele pakub Aavik välja mõned hinnangud konkreetsete verbide ja verbirühmade totaal- või partsiaalobjektilembuse kohta: „[Partsiaalobjekti soodustav] mõju aga ei ole ega tohi olla kõigil verbidel ühesugune: tugevam on see verbidel „tahan, soovin, igatsen, tohin, püüan, katsun” jne. (üldse tahte- ja tundeverbidel); väiksem verbidel „võin, saan, suudan, 
oskan, mõistan, mõtlen, kavatsen, loodan" jne.; - peaaegu olematu verbidel „pean, otsustan"” (Aavik 1936: 133). Väärib mainimist, et Aaviku kasutatud termin „tahte- ja tundeverbid” kattub suuresti eelmises alaosas välja toodud esimese verbirühmaga: „soovi, kavatsust või muud tunnet väljendavad verbid”.

Oluline on siinkohal mainida, et tsiteeritud autorite hinnangud käivad enamasti objektikonstruktsiooni ühe alltüübi, soovimis-kavatsemiskonstruktsiooni kohta. Erandiks on ainult Aavik, kes käsitleb soovimis-kavatsemisverbide kõrval ka modaalverbe. Küsimust, kas konstruktsiooni alltüüpide eristamine on objekti käände varieerumise seisukohalt üldse põhjendatud, arutatakse käesoleva artikli 3. ja 4. peatükis.

\section{Materjal ja meetod}

Üksikute korpusenäidete alusel ei ole võimalik otsustada (Aaviku seletust järgides) finiitverbi ja infinitiivi suhtelise tähtsuse või (Taulit järgides) soovi/ tahte/kavatsuse tugevuse üle. Need on subjektiivsed tunnused, mille väärtusele konkreetses näitelauses ei pruugi viidata miski peale (võib-olla) objekti käände enda. Küll aga on võimalik võrrelda objekti käänete kasutust erinevate finiitverbidega, et näha, millised verbid soodustavad üht või teist objekti käänet. Sel eesmärgil on korpusest etTenTen analüüsiks kogutud 3400 lauset 17 erineva finiitverbiga (iga finiitverbi kohta 200 lauset).

Vaadeldavate finiitverbide hulgas on esindatud kõik objektikonstruktsiooni alltüübid: soovimis-kavatsemiskonstruktsioon (julgema, kartma, kavatsema, lootma, proovima, pü̈̈dma, soovima, tahtma, üritama, ähvardama), modaalkonstruktsioon (oskama, saama, suutma, tohtima, võima) ning võimaldamis-kohustamiskonstruktsioon (soovitama, võimaldama). Konkreetsed verbilekseemid on valitud sageduse (et vajaliku hulga lausete kogumine oleks võimalikult lihtne) ja semantilise mitmekesisuse järgi. Selleks et paremini isoleerida verbilekseemide endi mõju objekti käändele, on analüüsist välja jäetud kõik laused, milles on täidetud vähemalt üks järgmistest kriteeriumidest:

1) finiitverb on eitavas vormis;

2) $d a$-infinitiiviga fraasiga kirjeldatud tegevus on piiritlemata (nt partitiivverbide objekt esineb alati partitiivis ning mingit varieerumist ei ole); tid);

3) objektinoomen on kvantitatiivselt piiritlemata (nt ainesõnalised objek-

4) objektinoomen on mitmuses (kuna mitmuse osastav võib tähistada nii objekti kvantitatiivset piiritlematust kui ka imperfektiivsust, on sageli raske otsustada selle tähenduse üle konkreetses lauses. Seega tuleb kõik mitmuse osastavas oleva objektiga laused analüüsist välja jätta, mistõttu tuleb kallutamata pildi saamiseks välja jätta ka mitmuse nominatiivis oleva objektiga laused);

5) objektinoomeniks on asesõna (kuna asesõnalised objektid käituvad mõnevõrra ebareeglipäraselt);

6) vormihomonüümia tõttu jääb objekti kääne ebaselgeks.

Lisaks sellele on käesolevas uurimuses piirdutud kindla kõneviisi oleviku vormis finiitverbi sisaldavate väitlausetega, kuna finiitverbi aeg võib ka mõjutada objekti käänet ning mõned verbid võivad esineda teatud ajavormis (nt minevikus) sagedamini kui teised. 


\section{Tulemused ning verbide tähendusrühmade analüüs}

Selles osas esitatakse arvulised tulemused ning illustreerivaid näiteid objekti käände varieerumisest. Tabelis 1 on kõigi 17 vaadeldud finiitverbi objekti käänete andmed (iga verbi kohta 200 lauset).

Tabel 1

\section{Partsiaalobjekti osakaal objektikonstruktsioonis erinevate finiitverbidega}

\begin{tabular}{|l|l|l|l|l|}
\hline Verb & $\begin{array}{l}\text { Partsiaal- } \\
\text { objekt }\end{array}$ & Totaalobjekt & $\begin{array}{l}\text { Partsiaal- } \\
\text { objekti \% }\end{array}$ & Alltüüp \\
\hline kartma & 166 & 34 & $83 \%$ & soov-kav \\
\hline üritama & 122 & 78 & $61 \%$ & soov-kav \\
\hline pü̈̈dma & 106 & 94 & $53 \%$ & soov-kav \\
\hline tahtma & 101 & 99 & $51 \%$ & soov-kav \\
\hline proovima & 97 & 103 & $49 \%$ & soov-kav \\
\hline soovima & 91 & 109 & $46 \%$ & soov-kav \\
\hline tohtima & 81 & 119 & $41 \%$ & modaal \\
\hline oskama & 54 & 146 & $27 \%$ & modaal \\
\hline võimaldama & 45 & 155 & $23 \%$ & võim-koh \\
\hline julgema & 31 & 169 & $16 \%$ & soov-kav \\
\hline saama & 28 & 172 & $14 \%$ & modaal \\
\hline lootma & 23 & 177 & $12 \%$ & soov-kav \\
\hline ähvardama & 20 & 180 & $10 \%$ & soov-kav \\
\hline suutma & 16 & 184 & $8 \%$ & modaal \\
\hline soovitama & 11 & 189 & $6 \%$ & võim-koh \\
\hline võima & 11 & 189 & $6 \%$ & modaal \\
\hline kavatsema & 3 & 197 & $2 \%$ & soov-kav \\
\hline Keskmine & 60 & 140 & $30 \%$ & \\
\hline & & & & \\
\hline
\end{tabular}

Järgnevalt esitatakse näiteid igast vaadeldud verbist (tabeli 1 järjekorras):

(7) Naised kardavad kaotada meest mitte ainult armastusest või kiindumusest, vaid kaitsetustundest ja hirmust, et peab hakkama iseennast ülal pidama.

(8) Briti valitsus üritab saavutada kanepi ümberklassifitseerimist B-klassi uimastiks.

(9) Anatoomikum, politseinik ja uurija püüavad uurida mõrva ning panna kildudest kokku surnud mehe viimast elupäeva.

(10) Tööle hakkamise algusest saadik oli Vanem Tütar teadnud, et tahab ühel päeval oma isiklikku talli rajada.

(11) Kui indekseerimine on lõppenud, proovime teha otsingu failidest, mis asuvad filefolder kataloogis.

(12) Ütlen välja nagu asi on - aitab naljast, soovin 2012 jooksul abieluettepanekut saada ja abielluda. 
(13) Avalikku kohta tohib prügikasti, pinki, tõkkepiiret, reklaamikandjat, jalgrattahoidjat või mistahes teisi teisaldatavaid väikevorme paigaldada vallavalitsuse loal.

(14) Isegi sellise kolm korda korduva lehtede tutvustuse oskab ta atraktiivseks rääkida.

(15) See võimaldab sportlasel saada üksikasjalikumat ülevaadet oma füüsilisest seisundist.

(16) Kui keegi julgeb raiuda kasvõi ühe puu, võtavad vaimud talt mõistuse või suretavad.

(17) Ärisaladuse hoidmise kohustus on juhatuse liikmel tähtajatult, mistõttu juhul, kui on võimalik tõendada äriühingule kahju tekitamist, saab vastavasisulise kahju ka juhatuse liikmelt sisse nõuda.

(18) „Pehme jõu” abil loodab Moskva luua riigist objektiivse pildi ja samal ajal parandada oma välispoliitika informatsioonilist kajastamist.

(19) Juba praegu hoiatavad majandusteadlased, et kasvav nafta hind ähvardab peatada globaalse majanduskasvu.

(20) Ksülitooli kasutavad ka suhkurtõbised: omastamine ei sõltu insuliinist ja temast suudab inimorganism sünteesida väikese glükoosikoguse.

(21) Ford soovitab ise iga $160000 \mathrm{~km}$ tagant läbi viia küünlavahetuse 5.4 Triton mootoritel.

(22) Korraliku auto võib leida ka Eestist, kuid tahtes valida keretüüpi, -värvi, varustust ja mootorit, tuleks ostusooviga pöörduda pigem Saksa turule.

(23) Televisioonis oleks alkoholireklaam lubatud alles pärast kella 21 ja kinodes kavatsetakse keelata alkoholireklaam alaealistele lubatud seanssidel.

Ülalpool on esitatud ainult üks näide iga verbi kohta, kuid tähelepanu väärib ka ühe ja sama verbi puhul toimuv varieerumine. Näiteks võib tuua järgmised kaks lauset verbiga soovitama, kus isegi $d a$-infinitiivis olev verb on sama, aga esimeses lauses esineb partsiaalobjekt, teises totaalobjekt:

(24) Soovitan valida autot auto enda järgi kui rahakott ei kannata esindusse minna.

(25) Seetõttu soovitamegi harrastajatel ja ka võistlevatel rulluisutajatel valida uisk enda taseme, mitte hinna järgi.

Näitepaaris verbiga kartma on mõlemas lauses ka sama objektinoomen:

(26) Imelik, kuidas muutuvad ajakirjanikud lojaalseks valitsusele, kui kardavad kaotada töökohta.

(27) Euroopas keskmiselt kardab kaotada töökoha 6 protsenti elanikest, Eestis aga 17 protsenti.

Sellised näited illustreerivad, et objekti käände valikut üksikutes lausetes ei pruugi olla võimalik seletada. Tegelik keelekasutus on siin nii ebajärjekindel, et rääkida saab ainult üldistest tendentsidest ja motivatsioonidest, mitte kindlatest põhjustest, miks ühes või teises lauses on kasutatud üht või teist käänet. 
Tabelist 1 selgub, et eri verbide vahel on üsna suured erinevused objekti käändekasutuse osas. Mitme vaadeldud verbi partsiaalobjekti osakaal on nullilähedane, veel viis-kuus verbi näitavad partsiaal- ja totaalobjekti enamvähem võrdset kasutust. Ainult ühel finiitverbil (kartma) on partsiaalobjekt selges ülekaalus. Keskmiselt on partsiaalobjekti osakaal $30 \%$, millest võib järeldada, et enamasti on $d a$-infinitiivi lekseem objekti käände seisukohalt tähtsam kui finiitverbi lekseem. Siinkohal korratagu, et analüüsitud on ainult piiritletud infiniitse fraasiga lauseid (st piiritletud nii infiniitverbi kui ka objektinoomeni poolest), mistõttu saab eranditult kõik partsiaalobjekti kasutusjuhud omistada kas konkreetsele finiitverbile või konstruktsioonile üldisemalt. See, et $d a$-infinitiivi mõju objekti käändele on vaadeldud materjalis oluliselt tugevam kui finiitverbi mõju, on ootuspärane, arvestades, et sama kehtib nt partitiivverbist $d a$-infinitiivi puhul, mis nõuab alati partsiaalobjekti, sõltumata finiitverbist, nt otsustasin seda etendust / *selle etenduse oma silmaga näha.

Kas aga leidub tähendusrühmi, millesse kuuluvad verbid käituvad objekti käände suhtes sarnaselt? Mingil määral küll. Sünonüümilähedaste verbide üritama, pü̈̈dma ja proovima partsiaalobjekti osakaal on vastavalt $61 \%$, $53 \%$ ja $49 \%$. Silma paistab ka tahtma (51\%) ja soovima (46\%) sarnasus. Veel üldisemalt võib öelda, et tulemused kinnitavad suures osas Johannes Aaviku intuitsiooni: partsiaalobjekti osakaal on verbidel tahtma, soovima, tohtima ja pü̈̈dma tõesti oluliselt suurem kui verbidel võima, saama, oskama, suutma, kavatsema ja lootma.

Ometi on lihtne leida vastunäiteid ehk samasse tähendusrühma kuuluvaid verbe, mille partsiaalobjekti osakaal erineb märkimisväärselt. Aaviku pakutud seletus, et partsiaalobjekti soodustav mõju on tugevam „tahte- ja tundeverbidel”, on üsna kahtlane. Kui (nagu eespool mainitud) verbide tahtma ja soovima partsiaalobjekti osakaal on $50 \%$ ringis, siis lootma-verbiga on partsiaalobjekt palju haruldasem, ainult $12 \%$. Nende kolme verbi semantiline sarnasus on ilmne: kõik väljendavad subjekti positiivset suhtumist võimalikku sündmusesse, vihjamata subjekti poolt kavandatavale või juba toime pandavale tegevusele selle sündmuse teostamiseks. Teisisõnu on selge, et lootma-verb kuulub oma tähenduse poolest tahte- ja tundeverbide hulka, millest tulenevalt võib tõdeda, et tahte- ja tundeverbid ei käitu objekti käände seisukohalt kaugeltki ühtemoodi. (Teine tahte- või tundeverb, mis soodustab tugevalt totaalobjekti, on kavatsema.)

Teiste võimalike suurte verbirühmade puhul on selge, et nad ei moodusta objekti käände seisukohalt mingisugust ühtset tervikut. Kõigepealt vaatame objektikonstruktsiooni kolme alltüüpi eraldi.

Soovimis-kavatsemiskonstruktsiooni kuuluvad kuus kõige partsiaalobjektilembesemat verbi: kartma, üritama, pü̈̈dma, tahtma, proovima ja soovima. Ometi, nagu juba mainitud, esindavad seda konstruktsiooni veel verbid lootma ja kavatsema, mis soodustavad väga tugevalt totaalobjekti. Seega on selge, et objekti käände seisukohalt ei ole tähtis see, et verb väljendab mingisugust soovi, kavatsust või tunnet, vaid pigem see, millist soovi, kavatsust või tunnet täpselt väljendatakse. Seejuures on võimalik eristada kahte selget (olgugi et väikest) alarühma. Esimene on katsetamisverbide rühm (üritama, pü̈̈dma, proovima), milles on partsiaal- ja totaalobjekti osakaal enam-vähem võrdne (vahemikus 49-61\%). Teine on valmisolekut väljendavate verbide 
rühm, millesse kuuluvad julgema (partsiaalobjekti osakaal $16 \%$ ) ja ähvardama $(10 \%)$.

Modaalkonstruktsiooni pilt on sarnane. Kuigi mõnel modaalverbil (võima, suutma, saama) on partsiaalobjekti kasutus üsna haruldane, siis teistel (tohtima, oskama) on see palju tavalisem. Jälle võib tõdeda, et määrav on konkreetne verbitähendus (või hoopis teised, verbi tähendusega mitteseonduvad tegurid), mitte modaalsus ise. Samas paistab, et modaalsuse tüüp (deontiline, dünaamiline või episteemiline) ei ole otsustav tegur, kuna dünaamilist modaalsust väljendavad verbid suutma ja oskama näitavad objekti käände osas väga erinevat käitumist (suutma partsiaalobjekti osakaal $8 \%$, oskama $27 \%$ ).

Võimaldamis-kohustamiskonstruktsiooni esindab käesolevas uurimuses ainult kaks verbi, võimaldama ja soovitama. Kuigi mõlema verbiga domineerib totaalobjekt, on partsiaalobjekt koguni neli korda sagedasem verbiga võimaldama. Ka siin paistab, et konstruktsiooni alltüüpide sisesed semantilised erinevused on objekti käände seisukohalt tähtsamad kui see, millisesse alltüüpi kuulub üks või teine verb.

Kokkuvõtteks on üsna raske moodustada verbirühmi, mis oleksid nii semantiliselt kui ka objekti käändekasutuse poolest ühtsed. Ainsad võimalikud kandidaatrühmad on nii väikesed (2-3 liiget), et nende sisemine sidusus võib olla juhuslik ega peegelda mingit sügavamat tõde objekti käändekasutuse kohta.

\section{Sündmuse toimumise tõenäosus objekti käände mõjurina}

On mitmeid põhjusi arvata, et objekti käändekasutus objektikonstruktsioonis võiks olla seotud sellega, kui suur on tõenäosus, et $d a$-infinitiiviga fraasis kirjeldatud sündmus tegelikult toimub. Esimene on partsiaalobjekti seos eitusega. Kui eitatud (ehk siis kindlasti toimumata jääva) sündmuse puhul on partsiaalobjekti esinemistõenäosus $100 \%$, siis on loogiline oletada ka üldisemat seost: mida suurem on sündmuse toimumise tõenäosus, seda tõenäolisemalt kasutatakse totaalobjekti. Sellele võimalusele viitab ka Tauli (1980), öeldes, et partsiaalobjekt väljendab nõrgemat ning totaalobjekt kindlamat soovi/tahet/ kavatsust. On ilmne, et mida kindlam on soov, seda suurem on tõenäosus, et inimene võtab ette vajalikud sammud selle soovi teostamiseks; nõrgemad soovid jäävad aga huvi või kindlameelsuse puudumise tõttu realiseerimata. Seost sündmuse toimumise tõenäosuse ja objekti käände vahel võib märgata ka ühes teises $d a$-infinitiiviga konstruktsioonis, nimelt hinnangukonstruktsioonis, milles predikaadis esinev omadussõna väljendab hinnangut $d a$-infinitiiviga fraasis kirjeldatud tegevuse kohta (Penjam 2008: 57). Kui selles konstruktsioonis esineb omadussõna võimatu, on partsiaalobjekt palju sagedasem kui siis, kui hinnangut andvaks omadussõnaks on võimalik. Kui võrrelda näiteks lauseid Selles linnas on võimatu leida hea töökoht/head töökohta ning Selles linnas on võimalik leida hea töökoht/head töökohta, siis esimeses lauses tundub totaalobjekt üsna imelik (võib-olla lausa vale), samal ajal kui teises lauses on mõlemad variandid vastuvõetavad. Ühes varasemas uurimuses (Ogren 2014: 174) olen leidnud, et partsiaalobjekti osakaal on omadussõnaga võimatu $94 \%$, sõnaga võimalik ainult $32 \%$.

Lisaks leiab see hüpotees tõestust ka käesoleva artikli 3. peatükis esitatud andmetes: võrdleme näiteks verbe tahtma (51\% partsiaalobjekti), soovima 
(46\%), lootma (12\%) ja kavatsema (2\%). Tahta või soovida võib igasuguseid võimatuid või äärmiselt ebatõenäolisi asju, aga lootmiseks on vaja, et loodetud sündmusel oleks ka mingi reaalne teostumisvõimalus. Iga laps võib soovida kunagi tulevikus presidendiks saada, kuid ainult reaalsed presidendikandidaadid võivad seda loota. Veel kindlamat soovi/tahet ning seetõttu suuremat teostumisvõimalust väljendab kavatsema, mis on ühtlasi vaadeldud verbidest kõige totaalobjektilembesem. Seega nende verbide kohta tundub kehtivat üldistus, et tõenäolisemate sündmuste puhul on totaalobjekt sagedasem.

Selle seletusega kaasneb on aga mitu probleemi. Kõigepealt on olemas mõned verbid ja verbirühmad, mille kohta see ei paista kehtivat, näiteks modaalverbid. Partsiaalobjekt on palju sagedasem verbiga tohtima (41\%) kui verbiga saama või võima (vastavalt $14 \%$ ja $6 \%$ ). Kas aga tegevus, mida tohib teha, on kuidagi ebatõenäolisem kui tegevus, mida saab/võib teha? Pigem võiks olla vastupidi - verb tohib lausa eeldab, et saab/võib küll, muidu poleks mõtet tohtimisest üldse rääkida (keegi ei ütle näiteks Päikesel tohib metssigu jahtida). (Meeldetuletuseks: käesolev analüüs puudutab ainult jaatavas vormis finiitverbiga lauseid. Tohtima-verb on üldiselt eituslembene, aga ka jaatuse korral on partsiaalobjekt palju sagedasem tohtima-verbiga kui teiste modaalverbidega, ja just sellele püütakse siin seletust leida.) Problemaatilised on ka oskama ja suutma, mis tunduvad olevat sündmuse toimumise tõenäosuse osas võrdväärsed: mõlemad väljendavad seda, et sündmuse toimumise eeltingimused on olemas, kuid ei sisalda ühtegi viidet sellele, et miski hakkaks tegelikult ka toimuma. Sellest sarnasusest hoolimata on partsiaalobjekt palju sagedasem verbiga oskama (27\%) kui suutma (8\%). Lisaks ei seleta sündmuse toimumise tõenäosuse kriteerium seda, miks partsiaalobjekti osakaal peaks olema palju väiksem (ja seega sündmuse toimumine palju tõenäolisem) verbiga ähvardama (10\%) kui verbidega üritama (61\%), pü̈̈dma (53\%) jne. Ähvarduses on alati olemas (kas eksplitsiitne või implitsiitne) tingimus, millest sõltub ähvarduse täideviimine või täide viimata jätmine; selle tinglikkuse tõttu ei ole usutav, et sündmuse toimumise tõenäosus võiks olla (keskmiselt) palju suurem verbiga ähvardama kui katsetamisverbidega üritama, püüdma ja proovima.

Tähtis on ka see, et kui sündmuse toimumise tõenäosus sõltub pigem konkreetsest situatsioonist kui verbilekseemist, siis objekti käände puhul on vastupidi. See vastandus tuleb esile, kui kokku panna totaalobjekti tugevalt soodustav finiitverb ning täiesti ebareaalset sündmust väljendav $d a$-infinitiiviga fraas. Näiteks kavatsema-verbi, mille puhul on totaalobjekti kasutus peaaegu absoluutne reegel, võib laiendada $d a$-infinitiiviga fraas, milles väljendatud sündmusel pole mingit reaalset toimumisvõimalust: Kavatsen Vaikse ookeani ühe päevaga tühjaks juua. Isegi kui kõneleja ise saab aru, et tema kavatsust on täiesti võimatu teostada, tuleb kasutada totaalobjekti, kuna kavatsemaverb seda nõuab. Objekti käände määrab siin finiitverb, mitte $d a$-infinitiiviga fraas.

\section{Subjekti agendilisus objekti käände mõjurina}

Vaadeldud finiitverbidest ainus, mis eelistab tugevalt partsiaalobjekti, on kartma (partsiaalobjekti osakaal $83 \%$ ). Ka see tulemus ei sobi kokku hüpoteesiga, et sündmuse toimumise tõenäosus mängib objekti käände valikul olu- 
list rolli. Vaadeldud 200-st kartma-verbi sisaldavast lausest kümnendikus on kardetud sündmuseks töökoha kaotamine, mida kindlasti ei saa pidada täiesti irreaalseks võimaluseks; neist 20 lausest 19-s (95\%) esineb partsiaalobjekt. Seega ei ole usutav, et kartma-verbi suhteliselt äärmuslik partsiaalobjektilembus võiks seletuda sündmuse toimumise (eba)tõenäosusega.

Kartma-verb eristub teistest vaadeldud verbidest aga kahe semantilise tunnuse poolest. Kõigepealt suhtub subjekt kardetud sündmusesse negatiivselt, samal ajal kui kõigi teiste verbide puhul on sündmus subjekti jaoks positiivne (kuigi ähvardama-verbil on ka negatiivne tähendusvarjund, on see negatiivsus suunatud kellelegi teisele; ähvardaja enda seisukohalt on ähvardatud sündmus positiivne, teenides tema eesmärki). Teiseks erineb kartma teistest verbidest selle poolest, et kui teiste finiitverbide subjekt võib ise pingutada $d a$-infinitiiviga fraasis väljendatud sündmuse teostamise nimel (nt finiitverb pü̈̈dma väljendab selgelt sellist pingutamist), siis kardetud sündmus toimub subjekti pingutustest hoolimata. Teisisõnu on subjekti mõju sündmuse toimumise tõenäosusele palju väiksem (võib-olla ka täiesti olematu) kardetud sündmuste puhul kui kavatsetud/soovitud sündmuste puhul. Seega ei ole kartma-verb omaette kategoorias ainult partsiaalobjekti sageduse poolest, vaid ka verbi semantika poolest. Eespool kirjeldatud tunnust, subjekti võimet mõjutada $d a$-infinitiiviga fraasis väljendatud sündmuse toimumise tõenäosust, nimetan edaspidi agendilisuseks. ${ }^{2}$

Sündmuse positiivsus/negatiivsus ei saa siiski olla objekti käänet määrav kriteerium, kuna on olemas väga suured verbidevahelised erinevused, mida ei saa selle abil kuidagi seletada. Võrdleme kas või verbe kavatsema (partsiaalobjekti osakaal $3 \%$ ) ja üritama (61 \%): mõlema puhul on subjekti suhtumine $d a$-infinitiiviga fraasis kirjeldatud sündmusesse positiivne, kuid objekti käände poolest kuuluvad nad täiesti eri kategooriatesse. Kartma-verbi teine omapära - subjektil ei ole arvestatavat mõju sündmuse toimumise tõenäosusele - on palju usutavam seletus, kuna subjekti agendilisus ehk võime tulemust mõjutada on tunnus, mille poolest võib täheldada erinevusi ka ülejäänud vaadeldud verbide hulgas (näiteks julgema-verbi subjektil on võime tulemust mõjutada selgelt tugevam kui lootma-verbiga). Samas sobib see kokku Tauli üldistusega, et kindlama tahte/soovi/kavatsuse jms puhul kasutatakse totaalobjekti: mida suurem on subjekti mõju tulemusele, seda kindlam on tulemus. Kartma-verbiga on tulemus (st sündmuse toimumine või toimumata jäämine) üsna ebakindel, mistõttu on ootuspärane, et selle verbiga domineerib partsiaalobjekt.

Kas ka teiste finiitverbide agendilisuse astmed langevad kokku nende eelistustega objekti käände osas? Sellele küsimusele vastamiseks on vaja esmalt kõik vaadeldud verbid liigitada nende agendilisuse järgi. Seda on raske päris objektiivselt teha ja paratamatult tuleb leppida ka rühmasiseste erinevustega, aga järgnevalt pakutakse üks võimalik liigitus:

${ }^{2}$ Termin agendilisus vastab käesolevas artiklis ingliskeelsele mõistele agency, mis viitab võimele tegutseda, otsustada, situatsiooni kontrollida vms. Keeleteaduslikku terminit agentiivsus (ingl agentivity), mis viitab agendi ehk aktiivse, teadliku, tahtliku tegija olemasolule situatsioonis, on siin teadlikult välditud. Rõhutatagu, et kuigi agendilisus on antud kontekstis finiitverbi tunnus, puudutab see siiski $d a$-infinitiiviga fraasis kirjeldatud sündmust. Näiteks lauses Ta saab osta raamatu on agendilisus kõrge, kuna saama-verb väljendab, et subjektil on tugev mõju $d a$-infinitiiviga fraasis kirjeldatud sündmuse (raamatu ostmise) teostumise või teostumata jätmise üle. 
1) madal agendilisus (subjekt on passiivne): lootma, kartma;

2) keskmine agendilisus (subjekt pingutab, kuid sündmuse toimumine või toimumata jäämine ei sõltu ainult temast): üritama, pü̈̈dma, proovima, tahtma, soovima, soovitama, võimaldama, kavatsema;

3) kõrge agendilisus (sündmuse toimumine või toimumata jäämine sõltub ainult subjektist): tohtima, oskama, saama, võima, suutma, julgema, ähvardama.

Kui kokku liita kõigi samasse rühma kuuluvate verbide andmed objekti käänete jaotuse osas, saame tulemuseks, et partsiaalobjekti osakaal on madala agendilisuse rühmas $47 \%$, keskmise agendilisuse rühmas $36 \%$ ja kõrge agendilisuse rühmas $18 \%$. See paistab toetavat hüpoteesi, et agendilisus on objekti käände valikul tõesti oluline (olgugi mitte kaugeltki o t s u s t a v) kriteerium.

Siiski on põhjust sellesse järeldusse kahtlevalt suhtuda. Esiteks tuleb mainida, et eeltoodud agendilisuse astmel põhinevad rühmad langevad suuresti kokku objektikonstruktsiooni alltüüpidega. Keskmise agendilisuse rühm koosneb valdavalt soovimis-kavatsemiskonstruktsiooni esindavatest verbidest; kõrge agendilisuse rühmas domineerivad modaalverbid (ja kõik vaadeldud modaalverbid ongi just selles rühmas). Peamised erinevused agendilisusel põhineva liigituse ning konstruktsiooni alltüüpidel põhineva liigituse vahel on, et agendilisusel põhinevas liigituses eristatakse mõned eripärased soovimis-kavatsemiskonstruktsiooni verbid (lootma, kartma, julgema, ähvardama) ning et võimaldamis-kohustamiskonstruktsiooni verbid soovitama ja võimaldama ei moodusta enam omaette rühma.

Teiseks oleks raske väita, et agendilisusel põhinev liigitus annab objekti käände osas kuidagi järjekindlama pildi. Madala agendilisuse rühm koosneb ühest äärmiselt partsiaalobjektilembesest verbist (kartma) ning ühest totaalobjekti tugevalt eelistavast verbist (lootma). Samasugust varieerumist leidub ka keskmise agendilisuse rühmas: katsetamisverbide üritama, püüdma ja proovima partsiaalobjekti osakaal on $50 \%$ ringis, samal ajal kui kavatsema, soovitama ja võimaldama-verbid eelistavad selgelt partsiaalobjekti. Lisaks jääb seletamata küsimus, miks tohtima-verbiga kasutatakse partsiaalobjekti oluliselt rohkem kui ülejäänud modaalverbidega. Kokkuvõtteks tuleb tõdeda, et rühmasisene varieerumine on liiga suur toetamaks hüpoteesi, et agendilisus mängib vaadeldud verbide objekti käände eelistustes olulist rolli. Sama võib öelda ka konstruktsiooni alltüüpide kohta.

\section{Kokkuvõte ja järeldused}

Kuigi erinevate finiitverbide vahel on suured erinevused objekti käändekasutuse osas, on väga raske neid erinevusi taandada mingisugustele konkreetsetele semantilistele tunnustele. $d a$-infinitiiviga fraasis väljendatud sündmuse toimumise tõenäosus, mis sõltub mingil määral ka verbilekseemist ning on mõnes teises $d a$-infinitiiviga konstruktsioonis väga tähtis objekti käände mõjur, osutub objektikonstruktsioonis ebaoluliseks. Subjekti agendilisus tundub kohati mingit rolli mängivat objekti käände valikul, kuid sellega kaasnevad liiga suured vastuolud (nt madala agendilisusega verbide kartma ja lootma kardinaalselt erinev käitumine objekti käände suhtes) selleks, et see võiks olla usutav seletus. 
Objektikonstruktsiooni kolm alltüüpi (soovimis-kavatsemiskonstruktsioon, modaalkonstruktsioon ja võimaldamis-kohustamiskonstruktsioon) näitavad küll oluliselt erinevaid eelistusi objekti käände osas, aga on küsitav, kas neid erinevusi saab omistada just alltüüpidele endile. Keskmiselt soodustavad nt soovimis-kavatsemisverbid partsiaalobjekti palju rohkem kui modaalverbid, kuid mõne soovimis-kavatsemisverbiga (lootma, kavatsema) on partsiaalobjekt siiski palju haruldasem kui paari modaalverbiga (tohtima, oskama), mis juba näitab, et objektikonstruktsiooni alltüübi kaudu on võimalik seletada ainult väikest osa verbidevahelisest varieeruvusest. Selle vastuolu lahendamiseks oleks vaja leida mingi semantiline või süntaktiline kriteerium, mille poolest lootma ja kavatsema erinevad teistest soovimis-kavatsemisverbidest ning tohtima ja oskama teistest modaalverbidest.

Nagu varem öeldud, ei paista sobivat semantilist kriteeriumi kuskilt leiduvat. Mis puutub süntaksisse, siis võib tõdeda, et verbid lootma ja kavatsema esinevad pigem komplekslausetes (kõrvallausest või infiniitfraasist laiendiga), erinevalt paljudest teistest soovimis-kavatsemisverbidest, mida kasutatakse sageli ka lihtlausetes, seejuures koos partsiaalobjektiga (nt kartma, tahtma, soovima). Seetõttu on võimalik, et assotsiatiivne seos partsiaalobjektiga on verbidel lootma ja kavatsema nõrgem kui verbidel kartma, tahtma ja soovima, mis omakorda võiks seletada, miks lootma ja kavatsema ei eelista objektikonstruktsioonis partsiaalobjekti. Sama loogika abil võiks seletada erinevusi ka teiste semantiliselt sarnaste verbide käitumises, näiteks oskama ja suutma (viimasega on partsiaalobjekt palju haruldasem). Sellele seletusele on aga üsna lihtne vastuväiteid leida. Verbi oskama kasutatakse sageli lihtlauses, partsiaalobjektiga; tohtima-verb ei tunne sellist kasutust üldse. Objektikonstruktsioonis on aga kõige partsiaalobjektilembesem modaalverb just tohtima. Samas on partsiaalobjekti osakaal veidi suurem katsetamisverbidega üritama, püüdma ja proovima kui tahtmisverbidega soovima ja tahtma, kuigi nimisõnaline (st mitte $d a$-infinitiiviga fraasist koosnev) partsiaalobjekt on viimaste puhul palju sagedasem. Veel üks vastunäide on soovitama, mis esineb sageli koos nimisõnalise partsiaalobjektiga, kuid mille partsiaalobjekti soodustav mõju objektikonstruktsioonis on väga nõrk (partsiaalobjekti osakaal $6 \%$ ). Seega on ebatõenäoline, et eri verbide nimisõnalise partsiaalobjektiga esinemise sagedus võiks oluliselt mõjutada nende objekti käände-eelistusi.

Kuna puudub üldine kriteerium, millele selliseid erinevusi omistada, siis jääb üle ainult üks seletus: objekti käände-eelistus (täpsemalt selle eelistuse tugevus, kuna tegemist on skalaarse tunnusega) $d a$-infinitiiviga objektikonstruktsioonis on olulisel määral finiitverbi lekseemi tunnus, mille väärtus ei ole verbi semantilistest või süntaktilistest omadustest usaldusväärselt järeldatav. Objekti käände rohket ja ettearvamatut varieerumist selles konstruktsioonis soodustab nii selgete valikukriteeriumide kui ka partsiaal- ja totaalobjekti vahelise olulise tähenduserinevuse puudumine.

Kuigi artiklis on räägitud partsiaalobjekti eelistavatest ja totaalobjekti eelistavatest finiitverbidest, siis tegelikult eelistavad kõik vaadeldud finiitverbid partsiaalobjekti, olles semantiliselt irresultatiivsed. Küsimus on selles, kas see eelistus on piisavalt tugev, et finiitverbi laiendava infiniitse fraasi vastupidine eelistus ehk totaalobjekti soodustav semantika üles kaaluda. Seega ei tähenda näiteks partsiaal- ja totaalobjekti võrdne esinemine vaadeldud konstruktsioonis finiitverbiga tahtma mitte seda, et tahtma-verbil endal ei ole selget objekti käände eelistust, vaid seda, et tahtma-verbi partsiaalobjekti soodustav 
mõju ja $d a$-infinitiivi vormis oleva verbi totaalobjekti soodustav mõju on võrdselt tugevad. Üldiselt aga selgub, et tugevam mõju on infinitiivil. Isegi kartmaverbil, mille partsiaalobjekti soodustav mõju on kõige tugevam, leidub arvestataval määral varieerumist (partsiaalobjekti osakaal $83 \%$, st totaalobjekti osakaal $17 \%$ ). Teises äärmuses, kus domineerib totaalobjekt, on varieerumist palju vähem: artiklis vaadeldud 17 finiitverbist koguni kaheksal on partsiaalobjekt haruldasem kui kartma-verbil totaalobjekt.

Artikli valmimist on toetanud Euroopa Liit Euroopa Regionaalarengu Fondi kaudu (Eesti-uuringute Tippkeskus) ning projekt PUT475 „Kirjakeele morfosüntaksi varieerumise integreeritud mudel: pilootuuring eesti keele näitel”.

\section{Võrguviited}

etTenTen. https://www.sketchengine.co.uk/ettenten-corpus/

\section{Kirjandus}

A a vik, Johannes 1936. Eesti õigekeelsuse õpik ja grammatika. Tartu: Noor-Eesti kirjastus.

Erelt, Mati 2006. Lause õigekeelsus. Juhatused ja harjutused. Tartu: Bookmill.

McWhinney, Brian, Malchukov, Andrej, Moravcsik, Edith (toim) 2014. Competing Motivations in Grammar and Usage. Oxford: Oxford University Press.

O gren, David 2014. Objekti kääne hinnangukonstruktsioonis: kas on võimalik osta auto või autot? - Emakeele Seltsi aastaraamat 59 (2013). Peatoim Mati Erelt. Tallinn: Teaduste Akadeemia Kirjastus, lk 171-192.

Penjam, Pille 2008. Eesti kirjakeele $d a$ - ja $m a$-infinitiiviga konstruktsioonid. (Dissertationes philologiae Estonicae Universitatis Tartuensis 23.) Tartu: Tartu Ülikooli Kirjastus.

Ta u li, Valter 1980. Eesti grammatika. II: lauseõpetus. Uppsala: Almqvist \& Wiksell.

\section{The influence of the finite verb on object case in the Estonian $d a$-infinitive object construction}

Keywords: differential object marking, variation, infinitives, constructions, agency

The present paper examines the influence of the finite verb on the choice of total vs. partial object in the Estonian $d a$-infinitive object construction. This construction consists of a finite verb modified by a $d a$-infinitive phrase which itself contains an object nominal, e.g. Tahan osta korteri/korterit 'I want to buy an apartment (gen/ part)'. The competition between the finite verb and the non-finite verb in determining the case of the object leads to substantial variation in usage. Moreover, some finite verbs favor the partial object, while others favor the total object.

The paper draws on corpus data to compare object case usage in the $d a$-infinitive object construction with 17 different finite verbs, covering a wide semantic 
range from verbs expressing a wish or intention to those expressing various types of modality. I explore the relationships (or the lack thereof) between object case usage and various semantic/syntactic features of finite verbs, attempting to identify groups of semantically and/or syntactically similar verbs that also behave similarly with respect to object case (i.e. show similar frequencies of the partial object relative to the total object) in the construction in question. In addition to simple semantically motivated groupings such as modals, verbs of trying, verbs of wishing etc., I also consider other features related to the finite verb such as the subject's degree of agency in the realization/non-realization of the event described in the infinitive phrase, the likelihood of the event occurring, and the propensity of the finite verb to appear with simple NP direct objects (as opposed to infinitive phrases containing an object).

The primary finding of the paper is that none of the features or categories examined show a clear relationship to object case. As such, the extent to which a given finite verb favors one object form over the other is largely a property of the verb lexeme itself and cannot be reliably predicted on the basis of its other semantic/syntactic features.

David Ogren (b. 1985), MA, University of Tartu, Institute of Estonian and General Linguistics,PhD student,david.ogren@ut.ee 